ROCZNIKI HUMANISTYCZNE

Tom LXVIII, zeszyt $6-2020$

DOI: http://dx.doi.org/10.18290/rh20686-11

AGNIESZKA SIERADZKA-MRUK

\title{
PRZEMIANY NABOŻEŃSTWA DROGI KRZYŻOWEJ W XX WIEKU W ŚWIETLE TEORII AKTÓW MOWY (WYBRANE ASPEKTY)*
}

Genologia lingwistyczna w opisie danego gatunku rozważa m.in. intencje komunikacyjne wyrażane przez ten gatunek, innymi słowy: bada, jakie akty mowy są zwykle realizowane w danym typie tekstów (np. „Wzorce gatunkowe wypowiedzi a realizacje tekstowe" 30). Używa się także m.in. określeń aspekt albo potencjał illokucyjny, wykorzystując pojęcie illokucji Austina (661). Właśnie aspektem illokucyjnym gatunku drogi krzyżowej zajmiemy się $\mathrm{w}$ tym opracowaniu (pomijając inne zagadnienia pragmalingwistyczne, jak np. opis sytuacji komunikacyjnej).

Jak wiadomo, nabożeństwo to polega na rozważaniu wydarzeń męki Chrystusa w połączeniu z przejściem symbolicznej drogi od miejsca skazania przez miejsce ukrzyżowania aż do grobu, w którym Jezus został pochowany. W klasycznej postaci droga krzyżowa składa się z 14 stacji. Przy każdej z nich na ogół odmawia się krótkie formuły modlitewne mające charakter względnie stały oraz wygłasza dłuższe rozważanie o charakterze relatywnie zmiennym.

Oczywistością jest twierdzenie, że nabożeństwo to jest zjawiskiem nie tylko językowym, ponieważ ważną rolę odgrywa posługiwanie się innymi kodami - przechodzenie od stacji do stacji, krzyże, zwykle także przedstawienia plastyczne poszczególnych stacji, często muzyka. Droga krzyżowa może być także realizowana w sposób niewerbalny, przez rozmyślanie o męce Pańskiej. W niniejszym opracowaniu o charakterze językoznawczym skoncentrujemy się jednak na warstwie językowej nabożeństwa.

Dr hab. AgnieszKa SieradzKA-MruK - adiunkt na Wydziale Polonistyki Uniwersytetu Jagiellońskiego, adres do korespondencji: Uniwersytet Jagielloński, Wydział Polonistyki, ul. Gołębia 18, 31-007 Kraków, e-mail: agnieszka.sieradzka-mruk@uj.edu.pl; ORCID: https://orcid.org/ 0000-0003-3075-1748.

${ }^{*}$ Niniejsze opracowanie zostało wygłoszone w postaci referatu w czasie konferencji „Polska kultura religijna" zorganizowanej przez Akademię Ignatianum w 2015 r. w Krakowie. 
Materiałem badawczym jest około dwustu tekstów drogi krzyżowej opublikowanych w XX wieku i na początku naszego stulecia, przy czym połowa mniej więcej została opublikowana w pierwszej połowie $\mathrm{XX}$ wieku, połowa pod koniec XX i na początku XXI wieku' ${ }^{1}$. Są to teksty zawarte w modlitewnikach, a także wydane w postaci broszurek i zbiorków dróg krzyżowych. W przypadku tekstów najnowszych część materiału znaleziono w Internecie na stronach diecezji, parafii, różnych stowarzyszeń religijnych, najwięcej na stronach internetowych kapucynów i dominikanów.

Należy zauważyć, że, ściśle biorąc, tekst opublikowany jako pomoc do odprawiania nabożeństwa nie jest tym samym, co tekst funkcjonujący w momencie odprawiania, ze względu na inną sytuację komunikacyjną, jednak w tym krótkim opracowaniu możemy omówić tylko najważniejsze akty mowy, na które okoliczność ta nie ma wpływu.

Droga krzyżowa jest więc zarazem gatunkiem mowy, jak i makroaktem mowy, który składa się z aktów cząstkowych ${ }^{2}$. Analizując intencje posłużymy się przede wszystkim znaną klasyfikacją aktów mowy Searle'a (1-23), jako najbardziej rozpowszechnioną, opartą na najjaśniejszych kryteriach, a zarazem korespondująca z teorią funkcji wypowiedzi Bühlera-Jakobsona (Bühler 29; „Poetyka w świetle językoznawstwa” 431-473). W podobny sposób teorie aktów mowy i funkcji wypowiedzi łączy Grzegorczykowa („Problem funkcji języka” 11-28), a także Puzynina („Funkcje języka” 163-172).

Jak wiadomo, Searle wyróżniał następujące rodzaje aktów: asertywy (reprezentatywy), których celem jest przedstawienie stanów rzeczy, np. podanie informacji, dyrektywy, których celem jest skłonienie odbiorcy do czegoś, jak np. prośby i rozkazy, komisywy, których celem jest podjęcie zobowiązania, np. obietnice, ekspresywy, których celem jest wyrażenie stanu psychicznego, zwłaszcza emocji, i deklaratywy, których celem jest stwarzanie stanów rzeczy, czyli wprowadzanie zmian w rzeczywistości, jak np. mianowanie kogoś na jakieś stanowisko, zalicza się tu też akty sakramentalne.

Z kolei w teorii funkcji wypowiedzi wyróżnia się funkcję skierowaną na nadawcę, czyli ekspresywną albo emotywną, która odpowiadałaby ekspresyw-

\footnotetext{
${ }^{1}$ Część tekstów mogła powstać wcześniej niż wskazuje na to data wydania. Sprzyjała temu praktyka przedrukowywania i parafrazowania, niekiedy łączenia w całość kilku starszych tekstów, na ogół bez podania źródeł, szczególnie rozpowszechniona na początku XX wieku. Istotny jest dla mnie rok wydania, a zatem czas funkcjonowania drogi krzyżowej w odbiorze wiernych, nie zaś rok powstania tekstu, trudny czasem do ustalenia. Poznanie pochodzenia i zależności między poszczególnymi tekstami wymaga odrębnych badań.

${ }^{2}$ Terminem makroakt posługuje się np. Skowronek w odniesieniu do reklamy (passim) albo a Makuchowska w odniesieniu do modlitwy (passim).
} 
nemu aktowi mowy, funkcje skierowaną na odbiorcę, zwaną impresywną, konatywną czy dyrektywną, odpowiadającą dyrektywnemu aktowi mowy, funkcję skierowana na rzeczywistość o której się mówi, zwaną przedstawieniową, poznawczą, reprezentatywną albo informatywną, odpowiadającą asertywnemu aktowi mowy. Roman Jakobson wymienia ponadto funkcje fatyczną, metajęzykową i poetycką, którymi nie będziemy w tym miejscu się zajmować. Należy też wspomnieć, że większość badaczy (Np. Grzegorczykowa, „Problem funkcji języka” 18; Skudrzykowa i Urban 109) z inspiracji Austina wyróżnia funkcję performatywną (inaczej stanowiącą lub sprawczą), która odpowiada aktowi deklaratywnemu. Niektórzy językoznawcy polscy, jak Grzegorczykowa („O specyficznych funkcjach” 79), Zdunkiewicz-Jedynak („Funkcja sakralna” 25) wymieniają też funkcję sakralną, która polega na uczestnictwie w sacrum. Jest rzeczą dyskusyjną, jak należy ją rozumieć, czy np. inne funkcje wypowiedzi religijnej uznać za przejawy tej funkcji czy za podporządkowane tej funkcji. Wydaje się, że to zależy od danego gatunku, kwestia ta wymaga jednak dalszych badań.

Porównanie różnych gatunków pasyjnych, jak np. Gorzkie żale, kazania pasyjne, modlitwy, pieśni wielkopostne i właśnie droga krzyżowa, pokazuje, że różne funkcje wypowiedzi, a zarazem akty mowy, wysuwają się w nich na plan pierwszy. Obok struktury nabożeństwa aspekt illokucyjny jest więc czynnikiem, który decyduje o specyfice danego gatunku.

Droga krzyżowa, jak się wydaje, ma przede wszystkim na celu odtworzenie kolejnych etapów męki Chrystusa w świadomości jej uczestników, czemu służą też różne środki pozajęzykowe, a zwłaszcza przechodzenie od stacji do stacji, od którego wywodzi się nazwa nabożeństwa. Odtworzenie to, w zależności od przyjętej definicji, można, jak sądzę, uznać za realizację funkcji sprawczej (performatywnej), a zatem za akt mowy deklaratywny w terminologii Searle'a. W tej konkretnej sytuacji funkcję sprawczą można uznać za szczególny przypadek (przejaw) funkcji sakralnej. Oczywiście wspomniane odtworzenie nie jest rzeczywistym powtórzeniem tych samych wydarzeń ${ }^{3}$. Nie jest też tego rodzaju odtworzeniem jak inscenizacja teatralna, chociaż pod pewnymi względami ją przypomina ${ }^{4}$. Ze względu na to, że zachodzi oddziaływanie na wyobraźnię uczestników nabożeństwa, mamy tu jednocześnie do czynienia $\mathrm{z}$ funkcją impresywną, zatem $\mathrm{z}$ wyrażonym pośrednio dyrektywnym aktem mowy.

\footnotetext{
${ }^{3}$ Według teologii katolickiej tzw. anamneza - 'uobecnienie wydarzeń zbawczych' zachodzi w liturgii, a nie w pozaliturgicznych formach pobożności (Nadolski 14).

${ }^{4}$ Problem ten wymaga dalszych rozważań.
} 
$\mathrm{Na}$ funkcję performatywną wskazują przede wszystkim komentarze metatekstowe (występują w wypadkach, gdy tekst mówi sam o sobie). Zwróćmy tu uwagę na czasowniki: przypomnieć, powtórzyć, uobecnić:

Przychodzimy do Ciebie, Panie Jezu [...], gdyż pragniemy przypomnieć sobie tamten Wielki Piątek sprzed dwóch tysięcy lat [...]. Pragniemy po raz kolejny w naszym życiu przejść z Tobą i za Tobą drogę Twojego krzyża (Dziewiecki) ${ }^{5}$. Rozpoczynam drogę krzyżową, która przypomina, a nawet uobecnia tę bolesną drogę Syna Bożego [...] (Nowak).

Mój Mistrzu [...] pragnę powtórzyć w sobie Twoje życie (Adonai I).

Osobistemu przeżyciu przez uczestników wspominanych wydarzeń sprzyjają wypowiedzi z czasownikami w 1.osobie czasu teraźniejszego, jak w poniższych przykładach:

Idziesz na śmierć za mnie i ja chcę pójść i umrzeć z Tobą [...] (redemptoryści 182).

O Maryjo! Idę za Tobą z Jezusem. Pójdźcie ze mną Aniołowie i wszyscy święci Pańscy [...] (Wiąz. mirry 163).

Jestem obok niewiast płaczących i płaczę razem z nimi (O współwinie).

$\mathrm{Z}$ bólem dostrzegam, że ja też jestem pośród tych, którzy skazali cię na śmierć (Dziewiecki).

Jezu, w duchu towarzyszę Twej Matce i widzę oczyma wiary Twój pogrzeb (Jura).

Autorzy rozważań używają wielu środków, aby wywołać w uczestnikach poczucie uczestnictwa w wydarzeniach zbawczych. Czynią to m.in. przez plastyczny opis, użycie wyrazów ekspresywnych, czasowników percepcji patrzeć i stuchać, oraz wspomnianych kategorii czasownika - osoby, liczby i czasu:

Patrz grzeszniku! jako bezbożni kaci biorą z furyją, wiążą i prowadzą na śmierć łotrowską (Wadowice 9).

Ach! patrz, jak ci niegodziwi ludzie kopią go nogami i biją pięściami [...] (Wilno 49).

Wznieś oczy i patrz na Jezusa, na krzyżu wiszącego. Słuchaj, jak się modli za tych co Go ukrzyżowali [...] (Częstochowa 33).

Na drodze krzyżowej jest wielu ludzi. Jedni idą za Jezusem, drudzy prowadzą Go na śmierć, inni stoją i tylko się patrzą [...] Przyjrzyj się sobie, gdzie jesteś [...]. Gdzie jesteś na drodze do Kalwarii? [...] Nie pytaj mnie, gdzie jestem! Jestem

\footnotetext{
${ }^{5} \mathrm{~W}$ tekstach pochodzących z Internetu nie podaję numerów stron. W tytułach i cytatach stosuję pisownię oryginalną, nie zawsze zgodną ze współczesną normą ortograficzną i interpunkcyjną.
} 
tam, jestem w thumie [...],gdzie krzyczą: Ukrzyżuj [...]. Krzyczę, bo wszyscy tak krzyczą. Krzyczę, bo nie chcę być innym (O współwinie).

Ostatni cytowany fragment zawiera typowe opowiadanie unaoczniające z tzw. praesens historicum. Wykorzystano ponadto kategorie pierwszej i drugiej osoby liczby pojedynczej czasownika dla stworzenia wirtualnego dialogu, który ma na celu zaangażowanie odbiorców.

Droga krzyżowa odtwarza mękę Jezusa, ale zarazem jest też niejako duchową pielgrzymką do Ziemi Świętej, co należy uznać również za przejaw funkcji performatywnej. Zobaczmy następujący fragment przedmowy:

\begin{abstract}
Możeś nieraz pragnął, pobożny czytelniku, widzieć te miejsca święte, w których żył i cierpiał nasz Zbawca, a osobliwie drogę oną bolesną, którą odbył Pan Jezus z Krzyżem na ramionach [...]. Otóż, Kościół święty podaje ci sposób zaspokojenia choć w części tego pragnienia, bez wybierania się aż za morze do Jerozolimy. Stacje bowiem Drogi Krzyżowej [...] czyż nie naśladują [...] stacyj Jerozolimskich? A papieże [...] czyż nie nadali takim Drogom Krzyżowym [...] odpustów, tych samych, których przedtem tylko w Jerozolimie można było dostąpić [...]? (Mycielski 3).
\end{abstract}

Takie komentarze pojawiają się $\mathrm{w}$ przedmowach do starszych tekstów nabożeństwa, z początku XX wieku, w materiale współczesnym ich nie znaleziono.

W skład badanego makroaktu drogi krzyżowej niemal zawsze wchodzi makroakt modlitwy, sygnalizowany przez zwroty do Boga, Maryi i świętych. Znajdujemy tu wiele aktów cząstkowych ponieważ, jak wiadomo, może być modlitwa prośby, uwielbienia, przeproszenia, dziękczynienia itp., czyli odpowiednio akty dyrektywne i ekspresywne, realizujące zatem funkcje impresywną i ekspresywną, ale także fatyczną, polegającą na dążeniu do nawiązania kontaktu z Bogiem. Pojawia się też akt komisywny: obietnica poprawy Zwykle akty te są wyraźnie rozpoznawalne, dzięki czasownikom performatywnym lub metatekstowym ${ }^{6}$, jak w przykładach:

[...] serdecznie ubolewam nad męką Twoją, a proszę Cię [...] abyś mnie raczył uwolnić od wiecznego potępienia [...] (Chrząszcz 241).

[...] wyznawam Cię Pana i Boga mego, oraz ze wszystkiego serca, ze wszystkiej duszy chwalę, wielbię i błogosławię (Aniół 385).

[...] dzięki Ci składam za tyle i tak pięknych sposobności [...] do cierpienia dla Ciebie [...] (Wilno 54).

${ }^{6}$ Jak wiadomo, czasownik performatywny to czasownik w 1. os. cz. teraźniejszego, którego wypowiedzenie jest równoznaczne $\mathrm{z}$ wykonaniem czynności, czasownik metatekstowy jest zasadniczo czasownikiem mówienia (niekiedy pośrednio odnosi się do czynności mówienia). W zasadzie każdy czasownik performatywny jest metatekstowym, odwrotna zależność jednak nie zachodzi. 
Proszę Cię, abyś raczył mnie uwolnić od lęku przed cierpieniem (Woźny).

$\mathrm{O}$ prawdziwą i głęboką wiarę prosimy Cię, Jezu (O współwinie).

Za wszystkich, którzy mają władzę opiniowania, decydowania, wydawania wyroków - o odwagę podejmowania obrony prawdy - modlę się, Panie (Solak).

Dziękuję, Ci, Boże, że wtedy, gdy ja wątpiłem, Ty nie zwątpiłeś we mnie nigdy (Adonai I).

Za wszystkie bluźnierstwa dokonywane przeciw Tobie i Twej Matce - przepraszamy Cię, Jezu (O współwinie).

Opłakujemy nasze grzechy i zaniedbania, obiecujemy poprawę. Przyrzekamy $\mathrm{Ci}$, że będzie lepiej (Korża).

Aktów modlitewnych nie omawiamy w tym miejscu szczegółowo, odsyłając czytelnika do książki Makuchowskiej poświęconej modlitwie (passim).

Obligatoryjnym elementem drogi krzyżowej wydaje się akt dyrektywny, który można określić najogólniej jako wezwanie do nawrócenia, Mamy tu do czynienia z funkcją impresywną. Funkcja ta wyrażona jest przez tryb rozkazujący, leksemy oznaczające powinność, jak trzeba, musieć, ale także przez rozmaite oddziaływanie pośrednie, o czym jeszcze wspomnimy.

Nawróć się więc od złości swojej ku Bogu tak cię miłującemu [...] (Bochnia 3).

Ach! nie odejdź stąd inaczej jak upamiętany i skruszony, a obejmując krzyż Zbawiciela twego, tak do niego wołaj [...] (Wilno 68).

Trzeba - jak Jezus - zaraz podnosić się, żałując za popełniony grzech i prosząc o miłosierdzie Boże (Fornal).

Ale spójrz na Jezusa - On idzie z Tobą mimo, że ciężar na Jego ramionach nie należy do Niego. [...] Ty musisz coś zmienić, w sobie, swoim życiu. Więc nie poddawaj się! Jezus wstał, a ty idź za nim... (Człow. wyzwol.).

Do dyrektywnych aktów mowy należy też zaliczyć rozmaicie wyrażoną perswazję, m.in. przy pomocy wyrazów wartościujących, argumentacji logicznej i na wiele innych sposobów, których szczegółowo nie będziemy w tym miejscu omawiać. Elementy takiej argumentacji wystąpiły w ostatnim cytowanym przykładzie, pojawiają się też niekiedy w starszym nabożeństwie, jak poniżej:

Zrozumiejmy, że za bagatelę, za głupstwo życia nikt dobrowolnie nie daję [...] Jeżeli tedy Jezus Chrystus umiera dobrowolnie, by nam życie Boże [...] przywrócić, to życie Boże musi być czymś niesłychanie wielkiem i ważnem. Umiejmy tedy cenić w nas to życie Boże i bronić go (Haduch 11).

Formę wnioskowania (argumentacji) podkreślają tu spójniki jeżeli... to, więc, tedy. 
Omawiamy tu tylko najważniejsze akty mowy ${ }^{7}$, ponieważ głównym naszym celem jest przedstawienie zmian potencjału illokucyjnego, które zaszły w nabożeństwie drogi krzyżowej w ciągu XX wieku.

Jedna $\mathrm{z}$ ważnych zmian polega na tym, że współcześnie wspomniane akty dyrektywnie polegają nie tylko na wezwaniu do nawrócenia, ale znacznie częściej są to konkretne, szczegółowe zalecenia, jak np.

Niech każda matka i ojciec zastanowią się, jak wychowują swoje dzieci (Fornal). Nigdy nie wolno zrezygnować z budowy pokoju w małżeństwie, rodzinie, środowisku pracy, narodzie (O pokój).

To moje zadanie: ocierać oblicze człowieka obciążonego nieszczęściem. Przywrócić nadzieję i radość strapionemu, przybliżyć mu Boga, podźwignąć go, a nie zepchnąć... Dobra słowo, wypowiedziane z serca i życzliwie, rozpogodzi niejedno zmartwienie ludzkie (Świerczek).

Poszczególne wydarzenia pasyjne są przez analogię odnoszone do wydarzeń z życia współczesnych uczestników nabożeństwa i traktowane jako przykład postępowania dobrego lub złego ${ }^{8}$. Oczywiście zjawisko to mieliśmy także w dawnych drogach krzyżowych, obecnie ulega wyraźnemu wzmocnieniu, a liczba konkretnych problemów moralnych poruszanych we współczesnych tekstach zwiększa się znacząco, co się przejawia np. w rozbudowaniu pola semantycznego grzechów oraz dobrych uczynków ${ }^{9}$, a także w nawiązywaniu drogi krzyżowej do formy rachunku sumienia (Wojtak, Współczesne modlitewniki 191).

Historia Jezusa ma słuchaczy czegoś nauczyć. Często Jezus jest przedstawiony jako ten, który uczy, jest podmiotem wypowiedzi lub adresatem prośby o nauczenie. Zobaczmy kilka przykładów, w których występuje uczenie się:

Ucz się z tego, drogie dziecko moje, że boleść, którą uczucia naturalne sprawiają, nie jest grzechem, lecz sposobnością do zasługi (Wiąz. mirry 165).

Niech się tu nauczy każdy od Zbawiciela swego męstwa, cierpliwości i miłości ku zawziętym na siebie ludziom (Wadowice 42).

Idźmy więc za krzyżem [...]. Idźmy na kolejna lekcję miłości (Kapucyni V).

Każdy pogrzeb uczy nas szacunku dla ludzkiego ciała (Z Maryją).

\footnotetext{
${ }^{7}$ Bardziej szczegółową analizę, ograniczoną jednakże wyłącznie do nabożeństwa współczesnego, zawiera nieopublikowany jeszcze tekst referatu wygłoszony przeze mnie na konferencji $J e-$ zyk religijny dawniej i dziś VII (UAM, Paradyż 2012).

${ }^{8} \mathrm{Na}$ temat działania zasady analogii $\mathrm{w}$ dyskursie religijnym zob. Wojtak, „Styl religijny” 108; Sieradzka-Mruk, ,Zasada analogii” 335-345).

${ }^{9}$ Mówiłam o tym w nieopublikowanym jeszcze referacie wygłoszonym w czasie konferencji Język religijny dawniej i dziś VIII (UAM, Poznań 2014).
} 
I z tego płynie dla nas nauka: wtedy kiedy krzyż wydaje się ponad siły [...], Wtedy kiedy czujemy się zmiażdżeni i bezsilni, rodzi się solidarność między Nim a nami - On przeszedł przez to (Życiński).

[...] uczysz nas nie poddawać się w ciężkich sytuacjach (Jura).

Można powiedzieć, że charakterystyczny dla współczesnej drogi krzyżowej jest akt uczenia (akt dydaktyczny). Sytuuje się on na pograniczu aktów asertywnych (informatywnych) i dyrektywnych, ponieważ $z$ jednej strony może być to przekaz pewnych wiadomości czy umiejętności, ale z drugiej strony mamy do czynienia z celowym wywieraniem wpływu na odbiorcę uczestnika drogi krzyżowej. We współczesnych tekstach następuje ogromne zwiększenie frekwencji czasowników uczyć, nauczyć i wyrazów pokrewnych. Sam wyraz nauczyć występuje 135 razy na 100 współczesnych dróg krzyżowych, podczas gdy kilka zaledwie razy w tekstach z pierwszej połowy $\mathrm{XX}$ wieku. Oto typowe przykłady:

Święta Weroniko, naucz nas wykorzystywać każdą okazję do czynienia dobra (Wiary).

Panie Jezu Chryste, który w milczeniu przyjąłeś niesprawiedliwy wyrok Piłata, naucz nas odpowiedzialności za wypowiedziane słowa i sądy (Dominikanie IV).

Panie Jezu, naucz nas widzieć, że Prawda nie zależy od ilości głosów oddanych w demokratycznym głosowaniu! (Barabasz).

Połączenie wyrazowe naucz nas powtarza się wiele razy i wobec tego można je nazwać frazemem charakterystycznym współcześnie dla tego gatunku (Chlebda passim).

$\mathrm{Z}$ kolei $\mathrm{w}$ nowych tekstach następuje wyraźne zmniejszenie wagi aktów o funkcji ekspresywnej (emotywnej).

Na początku XX wieku przeżywanie uczuć było przedstawiane jako jeden z głównych celów drogi krzyżowej, Odwołajmy się do wypowiedzi metatekstowej kończącej nabożeństwo:

[...] dziękuję Ci najpokorniej za dobre myśli i uczucia, jakie w ciągu tej drogi krzyżowej pod słońcem łaski Twojej, weszły na jałowej niwie duszy mojej! Przebacz oziębłości i wszystkim niedostatkom moim! (Podgórze 30-31).

Przeżycie współczucia dla Jezusa miało doprowadzić do uświadomienia sobie własnej winy, a następnie do nawrócenia (pojętego, jak wspomnieliśmy, dość ogólnie). Dobitnie ilustruje to następujący bardzo emocjonalny cytat: 
[...]. Alem oto u nóg Twoich bolejący i skruszony, już raz na zawsze chcę zaniechać grzechu, a bolejąc, jęcząc, i wzdychając, stokroć i tysiąckroć powtórzę to postanowienie moje: O Boże mój! Boże, nigdy ach nigdy grzeszyć już nie będę (Wilno 62).

W dawnych tekstach spotykamy liczne wezwania do przeżywania uczuć:

Dopomagaj żalu tego Maryi, a nie spuszczaj nigdy zapłakanego oka z Jezusa (Chrząszcz 247).

Uważaj to duszo pobożna i we łzy się rozpływaj (Jezus 347).

Przykładów realizacji funkcji ekspresywnej w dawnym nabożeństwie jest bardzo wiele:

Najukochańszy mój Jezu! w ciężkości żalu mego rzucam się niżej piekła z najgłębszą pokorą przed Tobą Panem moim wywdzięczając tem tak ciężki upadek Twój [...] (Aniół 354).

O! jakby obfite wylewać trzeba łzy! O jakby nad Tobą z miłości umierać potrzeba. [...] Ale cóż, kiedy oziębłe i zatwardziałe serce moje wzruszyć się nie może! (Leszno 23).

Znajdujemy tu liczne środki wyrażania emocji, m.in. wykrzykniki i wykrzyknienia (czyli interiekcje i eksklamacje), powtórzenia, hiperbole, jak umieranie z miłości, rozpływanie się we łzach, uniżanie się „niżej piekła” itd.

Zestawmy te przykłady ze współczesnymi wypowiedziami metatekstowymi:

Pomóż mi, by moja droga krzyżowa nie byla jedynie pobożnym uczuciem chwili. Pomóż nam towarzyszyć Ci nie tylko szlachetnymi myślami, lecz przejść Twoją drogę sercem, nawet więcej: konkretnymi uczynkami codziennego życia (Koloseum).

Płaczące niewiasty to obraz tych wszystkich, którzy być może szczerze, ale jednocześnie tylko zewnętrznie i sentymentalnie reagują na biedę, na cierpienie, na niesprawiedliwość, bez zaangażowania się, bez podjęcia konkretnych kroków mających na celu zmniejszenie zła i biedy w świece (...). Jezu - wstrząśnij mną, abym dostrzegł, że i ja mam coś więcej do zrobienia niż tylko „serdecznie się wzruszyé" (Dk.homilie).

Obecnie zatem jednym z ważniejszych celem nabożeństwa jest skłonienie uczestników do czynnej postawy wobec świata, funkcja ekspresywna jest w znacznie większym stopniu niż dawniej podporządkowana funkcji impresywnej. Wyrazy sentymentalizm, sentymentalny, sentymentalnie wyraźnie są obciążone negatywnymi konotacjami. Oczywiście byłoby pewnym uprosz- 
czeniem powiedzieć, że współczesne nabożeństwo nie jest ekspresywne, tu także możemy znaleźć mnóstwo środków wyrażania emocji, jak w poniższych cytatach:

Ileż to razy w moim codziennym życiu wygodnie i po cichutku umywam ręce [...], bo po co się szarpać i nadstawiać niepotrzebnie karku? [...] wolę się odciąć, zbyć sprawę, być malutki i nijaki, byle tylko sobie nie zaszkodzić, byle nie zaszkodzić swojej karierce (...) (Konformistów).

Stoję obok Cyrenejczyka i patrzę jak pomaga nieść krzyż i strach rozdziera moje serce. Boję się, boję się, że Bóg odwróci swe oczy do mnie i mnie zawoła do pomocy w dźwiganiu krzyża (O współwinie).

W pierwszym cytowanym fragmencie możemy zauważyć m.in. środki słowotwórcze, jak po cichutku, malutki, karierka, które podkreślają ironię wypowiedzi. W drugim m.in. metaforę i powtórzenie w funkcji ekspresywnej: strach rozdziera moje serce. Boję się, boję się.

W wielu współczesnych tekstach można znaleźć także wyrazy nacechowane emocjonalnie, niejednokrotnie kolokwializmy, jak np. świństwo, gadanie, normalka (Konformistów), tajdactwo, wytgać się (Gierula), obciach ${ }^{10}$. Istnieje jednak także nurt unikający typowych sposobów wyrażania emocji, w badanym materiale należą tu np. teksty autorstwa ks. Stańka ${ }^{11}$.

Możemy zauważyć także poważne zmiany uchwytne statystycznie. Przykładowo weźmy pod uwagę wykrzykniki, takie jak ach i och, którym przypisuje się głównie lub nawet wyłącznie funkcję ekspresywną. Okazuje się, że w drodze krzyżowej z pierwszej połowy XX wieku mogło wystąpić nawet 70 wykrzykników w jednym tekście, natomiast w większości współczesnych tekstów nie ma ani jednego wyrazu tego typu ${ }^{12}$. Jak się wydaje, dotyczy to także zmniejszenia frekwencji wykrzyknień (eksklamacji) czy np. użycia kategorii superlatywu, jak: najmilszy, najdobrotliwszy. Współczesna droga krzyżowa jest także tekstem względnie emocjonalnym, ale emocje wyraża się w niej rzadziej, w inny sposób, mogą to być też inne emocje ${ }^{13}$, nie uważa się także wyrażania i wzbudzania emocji za istotny cel nabożeństwa, jak widać w cytowanych wyżej wypowiedziach metatekstowych.

$\mathrm{Na}$ koniec rozważmy jeszcze jedną istotną różnicę. Na początku XX wieku tekst nabożeństwa często nosił następujący tytuł:

\footnotetext{
${ }^{10}$ Zasłyszane w krakowskiej parafii.

${ }^{11} \mathrm{np}$. (Wiary), (O mądrość), (Starości).

12 Szczegółowo na ten temat: Sieradzka-Mruk „Zmiany w funkcjonowaniu” 37-50.

${ }^{13} \mathrm{Na}$ temat pola semantycznego nazw uczuć zob. Sieradzka-Mruk „Radość i nadzieja” passim.
} 
Droga Krzyża Jezusowego, to jest nabożeństwo, które kiedy kto nabożnie odprawi, otrzyma odpusty, które otrzymują nawiedzający miejsca święte w Jeruzalem (m.in. Aniół 345).

Cytowany tytuł występuje w badanym materiale kilka razy w tej właśnie utrwalonej postaci, np. (Chrząszcz 238); (Jezus 330); (Grudziądz 188), co wskazuje na to, jak ważna w odczuciu ówczesnych uczestników nabożeństwa była kwestia odpustów. Uzyskanie odpustu to bez wątpienia przejaw funkcji sprawczej, czyli performatywnej, a zatem akt deklaratywny. Jak wiadomo, obecnie za odprawienie drogi krzyżowej można uzyskać odpust zupełny pod pewnymi warunkami (Enchiridion Indulgentiarum). Odpust ten nadał drodze krzyżowej Pius XI w 1931, wcześniej były różne odpusty za różne stacje, co miało nawiązywać do odpustów za nawiedzenie Ziemi Świętej (Smereka 37), (Kopeć 20-21). I tak np. za stację śmierci Jezusa na krzyżu był odpust zupełny, ale za stację drugiego upadku odpust 7 lat $i$ tylez kwadragen $^{14}$ (np. Gniezno 18). Przywiązywano do tego bardzo dużą wagę, właściwie w każdym tekście z pierwszej połowy XX wieku mówi się o odpustach, szczególnie we wstępnej modlitwie, która niekiedy nazywa się Intencja:

[...] racz mi udzielić łaski dla dostąpienia wszystkich odpustów przy każdej stacji pozwolonych, z których jeden zupełny duszy mojej aplikuję, inne zaś wszystkie za dusze w czyścu zostające ofiaruję [...] (Wadowice 7).

Przytem, Najdroższy Jezu, pragnę otrzymać te odpusty, które są pozwolone odprawiającym to nabożeństwo. $Z$ tych jeden odpust zupełny ofiaruję za mnie samego(ą), a inne za dusze w czyśćcu cierpiące, jako się Tobie najlepiej podoba (Przyjdź 173-4).

Dobitność, z jaką artykułowana była prośba o odpusty, przypomina nieco podania urzędowe, pokazując sposób myślenia ówczesnych katolików. Kwestię tę naświetla następujący fragment zaczerpnięty z przedmowy pochodzącej z początku XX wieku:

Pierwszy Odpust zupełny, który jest przy pierwszej Stacyi, applikuj sobie samemu, inne zaś odpusty dla ciebie służyć nie mogą, gdyż jednego dnia więcej jak jednego Odpustu zupełnego dostąpić nie podobna. Więc ich applikuj komu innemu, to jest Duszom w Czyszczu (sic!) zostającym. Nie jest zaś dosyć uczynić ogólnie intencją, iż chcesz pozyskać wszystkich Odpustów Stacjom pozwolonych [...], ale potrzeba do każdej Stacyi inszą uczynić intencją: naprzykład w pierwszej stacij (sic!) mów myślą: Odpust w tej pierwszej Stacij [sic!] pozwolony chcę pozyskać, dla siebie samego pragnąc, aby mocą onego przez niewinną Mękę Syna Boskiego darowane mi było wszystkie karanie, na które grzechy moje zasłużyły. W drugiej stacij oświadcz intencją, iż Odpust przy tej pozwolony, chcesz applikować

\footnotetext{
${ }^{14}$ Kwadragena to okres czterdziestodniowy.
} 
za duszę N. naprzykład: Piotra, który podobno czyszcowemi mękami dług swój wypłaca. (...) i tak przy każdej stacij osobliwszą należy uczynić intencją, inaczej pozwolonych tak wielkich Odpustów nie dostąpisz (Łuków 3-4).

Przywiązywano, jak widać, wielką wagę do wyraźnego sformułowania intencji pod groźbą utraty odpustu. Natomiast w tekstach najnowszych niemal w ogóle nie spotyka się wzmianek na ten temat.

W niniejszym krótkim opracowaniu mogliśmy omówić tylko najważniejsze dla tego gatunku akty mowy. Podsumowując, należy zauważyć, że zmienia się hierarchia ich ważności. Przede wszystkim akty dyrektywne, a zwłaszcza akt dydaktyczny, zaczynają dominować nad aktami ekspresywnymi (wyrażeniem żalu za grzechy oraz współczucia dla Jezusa). Wyraźnie mniejszą wagę przywiązuje się też do aktu sprawczego (deklaratywnego czy performatywnego) polegającego na uzyskaniu odpustu. Znaczna część tych zmian wydaje się związana z przemianami w Kościele katolickim, które zaszły po soborze watykańskim II, a których nie jesteśmy w stanie dokładnie omówić w tym miejscu. Natomiast ewolucja sposobu wyrażania emocji zachodzi raczej stopniowo w ciągu XX wieku, co wymaga szczegółowych badań. Jednakże należy podkreślić, że podstawowy zestaw aktów mowy nie ulega zmianie i w tym sensie można mówić o stałości nabożeństwa drogi krzyżowej.

\section{ŹRÓDŁA CYTOWANE}

Adonai I = Droga Krzyżowa I, adonai.pl/modlitwy. Dostęp 15.03.2013.

Aniół ${ }^{15}=$ „Droga Krzyża Jezusowego to jest nabożeństwo, które, kiedy kto nabożnie odprawi, otrzyma te odpusty, które otrzymują nawiedzający miejsca św. w Jeruzalem”, Aniót Stróż chrześcijanina katolika. Zbiór modtów i pieśni stużacy dla dusz pobożnych. Z dodatkiem nieszporów i pieśni łacińskich, Grudziądz, nakładem wydawnictwa dzieł katolickich G. Jalkowskiego, [1902?], b.r.w., ss. 345-388.

Barabasz = Rozważania o Drodze Krzyżowej, armii Barabasza i końcu wieku XX, www.domini kanie.com. Dostęp 15.03.2013.

Bochnia = Droga Krzyżowa ułożona przez św. Leonarda de Porto Mauricio, które to nabożeństwo corocznie w kolizeum (sic!) w Rzymie uroczyście się obchodzi, Bochnia, nakładem księgarni W. Hillenbranda, 1900.

Chrząszcz, Jan, „Droga Krzyża Jezusowego, którą , gdy kto nabożnie odprawi, otrzyma te odpusty, które otrzymują nawiedzający miejsca św. w Jeruzalem", Jezus, Marya, Józef, moi niebiescy Towarzysze $w$ życiu i śmierci. Ksiązka do nabożeństwa dla wygody chrześcijan-katolików,

${ }^{15}$ Bardzo często, zwłaszcza w starszych modlitewnikach, pomijano datę wydania (czasami także miejsce, nazwę wydawnictwa lub inne dane). Przybliżoną datę ustalamy wówczas na podstawie zamieszczonej w modlitewniku tablicy świąt ruchomych lub daty imprimatur. 
opracowat ks. J. Chrząszcz, Warszawa i Wimperk, zakład katolickich wydawnictw i drukarnia J. Steinbrenera, 1914, ss. 238-268.

Częstochowa $=$ Nabożeństwo wielkopostne. Droga Krzyżowa i Gorzkie żale czyli rozpamiętywanie Męki Pańskiej, Częstochowa, zakład katolickich wydawnictw i drukarnia: wydawnictwo T. Nagłowski i s-ka, 1930.

Człow. wyzwol. = Droga Krzyżowa człowieka wyzwolonego. Krucjata Wyzwolenia Człowieka, www.mbgk.info/lit/wp/droga.html. Dostęp 15.03.2013.

Dk.homilie V = Droga Krzyżowa V, www.dk.homilie.org. Dostęp 15.03.2013.

Dominikanie IV = Droga Krzyżowa IV, www.dominikanie.com. Dostęp 15.03.2013.

Dziewiecki, Marek, Rozważania drogi krzyżowej. Miłość, która zaskakuje, www.oat. com.pl. Dostęp 15.03.2013.

Fornal, Andrzej, Przez śmierć do zmartwychwstania, www.opoka.org.pl. Dostęp 15.03.2013.

Gierula, Jerzy, Droga krzyżowa 1999, http://th-www.if.uj.edu.pl/ gierula/Parafia/ Rekolekcje/ wpost99/viaxy.htm. Dostęp 15.03.2013.

Gniezno - Droga krzyżowa z wizerunkami stacyj oraz Litanja o męce Pańskiej, Gniezno, nakładem Drukarni J.B. Lange, 1935.

Grudziądz = „Droga Krzyża Jezusowego to jest nabożeństwo, które, gdy kto nabożnie odprawi, otrzyma te odpusty, które otrzymują nawiedzający miejsca św. w Jeruzalem", Wyborek czyli krótki sposób nabożeństwa codziennego dla rzymsko-katolików z dodatkiem pieśni, Grudziądz, nakładem wydawnictwa dzieł katolickich G. Jalkowskiego, [1906?], b.r.w., ss. 188-220.

Haduch, Henryk, Śladami Chrystusa. Krótkie rozmyślania na temat drogi krzyżowej, Kraków, nakładem wydawnictwa księży jezuitów, 1921.

Jezus $=$ „Droga Krzyża Jezusowego to jest nabożeństwo, które, kiedy kto nabożnie odprawi, otrzyma te odpusty, które otrzymują nawiedzający miejsca św. w Jeruzalem”, Jezus, Marya, Józef. Zbiór codziennego nabożeństwa na chwate Boga, cześć Najświętszej Maryi Panny i Świętych Pańskich oraz pieśni nabożnych, Częstochowa - Warszawa, J. Bajdecki, [1921?], b.r.w., ss. 330-351.

Jura, Józef, Droga Krzyżowa dla cierpiacych, Droga Krzyżowa XX, www.drogakrzyzowa. kapucyni.pl. Dostęp 15.03.2013.

Kapucyni V = Droga Krzyżowa V, www.drogakrzyzowa.kapucyni.pl. Dostęp 15.03.2013.

Koloseum = Jeśli ziarno pszenicy nie obumrze... Droga Krzyżowa - Koloseum 2005, www.mbgk. info/lit/wp/droga.html. Dostęp 15.03.2013.

Konformistów = Droga krzyżowa I (konformistów...), wielkipost.awardspace.com. Dostęp 15.03.2013.

Korża, Henryk, Droga Krzyżowa w intencji trzeźwości narodu, www.oat.com.pl. Dostęp 15.03.2013.

Leszno = Droga krzyżowa czyli obchód stacyj pasyjnych, Gorzkie żale i pieśni o Męce Pańskiej, Leszno, księgarnia nakładowa i wysyłkowa S. i J. Bogaczyk, 1931.

Łuków = Droga Krzyżowa okropnej męki Chrystusa Pana dla Okupu Narodu Ludzkiego krwawemi śladami utorowana przez Stolice Apostolska Duszom prawowiernym do zbawiennej uwagi w XIV. Tajemnicach podana, Łuków, wydawca S. Jabłoński, 1920.

Mycielski = Droga Krzyżowa ułożona przez ks. M. Mycielskiego T.J. i Gorzkie żale, Kraków, nakładem Apostolstwa Modlitwy, 1926.

Nowak, Stanisław, Droga Krzyżowa, www.niedziela.pl. Dostęp 15.03.2013. 
O mądrość = Staniek, Edward, Modlitwa o mąrość. Droga Krzyżowa XIII, www.droga krzyzowa.kapucyni.pl. Dostęp 15.03.2013.

O pokój = Staniek, Edward, Modlitwa o pokój. Droga Krzyżowa XII, www.drogakrzyzowa. kapucyni.pl. Dostęp 15.03.2013.

O współwinie = Droga Krzyżowa o wspótwinie, strachu $i$ obojętności, www.dominikanie.com Dostęp 15.03.2013.

Podgórze = Droga krzyżowa. Gorzkie żale. Wybór pieśni o męce Pańskiej, Podgórze, nakładem L. Poturalskiego, 1903.

Przyjdź = „Droga Krzyżowa”, Przyjdź królestwo Twoje. Książeczka do nabożeństwa zawierajaca zbiór modlitw, stacji, Gorzkich żali $i$ pieśni dla płci obojga, Częstochowa, drukarnia B. Swięckiego, [1926?], b.r.w., ss. 174-190.

Redemptoryści = „Droga krzyżowa (św. Alfonsa)”, Książka misyjna oo. redemptorystów, Kraków, nakładem oo. redemptorystów, 1930, ss. 181-198.

Solak, Joanna, Droga krzyżowa, www.akdwp.pl. Dostęp 15.10.2011.

Starość = Staniek, Edward, Prośba o taskę dobrego wykorzystania starości. Droga Krzyżowa XVIII, www.drogakrzyzowa.kapucyni.pl. Dostęp 15.03.2013.

Świerczek, Stanisław, Droga krzyżowa miłosierdzia, www.drogakrzyzowa.kapucyni.pl. Dostęp 15.03.2013.

Wadowice = Droga Krzyżowa Zbawiciela świata Jezusa Chrystusa czyli Stacye rzymskie podtug od stoletnych (sic!), Wadowice, nakładem i drukiem Franciszka Foltina, 1903.

Wiary = Staniek, Edward, Panie, przymnóż nam wiary. Droga krzyżowa XVII, www.droga krzyzowa.kapucyni.pl. Dostęp 15.03.2013.

Wiąz. mirry = „Droga Krzyżowa”, Wiązanka mirry. Rozmyślania na cześć Przenajświętszej Męki Zbawiciela $i$ ćwiczenia duchowne z rozmaitych ksiag pobożnych zebrane, Warszawa, drukarnia F. Czerwińskiego, 1900, s. 163-169.

Wilno - Nabożeństwo na Post Wielki: komplety, Gorzkie żale, droga krzyżowa z dodatkiem pieśni wielkopostnych oraz przygotowanie do św. spowiedzi, Wilno, nakładem „Przyjaciela Ludu”, 1908.

Woźny, Aleksander, Droga Krzyżowa I, th-www.if.uj.edu.pl/ gierula/Parafia/Rekolekcje/wpost99/ viaxy.htm. Dostęp: 15.03.2013.

Z Maryją = Droga krzyżowa $z$ Maryja, www.dominikanie.com. Dostęp 15.03.2013.

Życiński, Józef, Droga krzyżowa, www.tygodnik.onet.pl. Dostęp 15.03.2013.

\section{BIBLIOGRAFIA}

Austin, John Langshaw. „Jak działać słowami”. John Langshaw Austin. Mówienie i poznawanie. Rozprawy i wyktady filozoficzne. Wydawnictwo PWN, 1993, ss. 543-743.

Bühler, Karl. Teoria języka. TAiWPN Universitas, 1934/2004.

Chlebda, Wojciech. Elementy frazematyki. Wyższa Szkoła Pedagogiczna im. Powstańców Śląskich w Opolu, 1991.

Enchiridion Indulgentiarum, www.vatican.va/roman_curia/tribunals/apost_penit/documents/rc_trib_ appen_doc_20020826_enchiridion-indulgentiarum_lt.html. Dostęp 4.04.2015. 
Grzegorczykowa, Renata. „O specyficznych funkcjach wypowiedzi religijnych”. Etnolingwistyka, 13, 2001, ss. 77-84.

Grzegorczykowa, Renata. „Problem funkcji języka i tekstu w świetle teorii aktów mowy”. Funkcje języka $i$ wypowiedzi, red. Jerzy. Bartmiński i Renata Grzegorczykowa, Język a Kultura, 4, „Wiedza o Kulturze”, 1991, ss. 11-28.

Jakobson, Roman. „Poetyka w świetle językoznawstwa”. Pamiętnik Literacki, 51, 1960, ss. 431-473.

Kopeć, Jerzy Józef. Droga krzyżowa. Duchowość nabożeństwa i antologia wspótczesnych tekstów polskich. Wydawnictwo Ojców Franciszkanów, 1994.

Makuchowska, Marzena. Modlitwa jako gatunek języka religijnego. Wydawnictwo TiT, 1998.

Nadolski, Bogusław. Liturgika, t. 2. Pallotinum, 1991.

Puzynina, Jadwiga. „Funkcje języka i akty mowy”. Polonistyka, 40, 1987, ss. 163-172.

Searle, John Roger. „A Classifiction of Illocutionary Acts”. Language in Society, 5/1, 1976, ss. 1-23.

Sieradzka-Mruk, Agnieszka. „,Radość i nadzieja, smutek i trwoga” w nabożeństwie drogi krzyżowej. Wybrane aspekty ewolucji dyskursu religijnego $w$ XX wieku na przyktadzie leksyki dotyczacej uczuć. Księgarnia Akademicka, 2016.

Sieradzka-Mruk, Agnieszka. „Adaptacje gatunkowe w tekstach współczesnej drogi krzyżowej”, Gatunki mowy $i$ ich ewolucja, t. V. Gatunek a granice, red. Danuta Ostaszewska, Joanna Przyklenk, Wydawnictwo Uniwersytetu Śląskiego, 2015, ss. 522-531.

Sieradzka-Mruk, Agnieszka. „Zmiany w funkcjonowaniu i częstości występowania wykrzykników (interiekcji) w rozważaniach drogi krzyżowej w ciągu ostatniego stulecia”. Język Polski, XCIV, z. 1 (2014), ss. 37-50.

Sieradzka-Mruk, Agnieszka. „Zasada analogii w homiliach kierowanych do odbiorcy dziecięcego". Stylistyka, t. XXI, 2012, ss. 335-345.

Skowronek, Katarzyna. Reklama. Studium pragmalingwistyczne. Instytut Języka Polskiego PAN, 1993.

Skudrzykowa, Aldona i Krystyna Urban. Mały słownik terminów z zakresu socjolingwistyki i pragmatyki językowej. Towarzystwo Miłośników Języka Polskiego, 2000.

Smereka, Wojciech. Drogi krzyżowe. Rys historyczny i teksty (studium pasyjne). Polskie Towarzystwo Teologiczne, 1980.

Wojtak, Maria. „Styl religijny w perspektywie genologicznej”. Język religijny dawniej i dziś, red. Stanisław Mikołajczak i Tomasz Węcławski, „Poznańskie Studia Polonistyczne”, 2004, ss. 104-113.

Wojtak, Maria. Współczesne modlitewniki w oczach językoznawcy. Studium genologiczne. Biblos, 2011.

Wojtak, Maria. „Wzorce gatunkowe wypowiedzi a realizacje tekstowe”. Gatunki mowy $i$ ich ewolucja, t. 2: Tekst a gatunek, red. Danuta Ostaszewska, Wydawnictwo Uniwersytetu Śląskiego, 2004, ss. 29-39.

Zdunkiewicz-Jedynak, Dorota. „Funkcja sakralna w tekstach i w języku. Perspektywa językoznawcy". Funkcje wypowiedzi religijnych, red. Renata Przybylska i Wiesław Przyczyna, Biblos, 2014, ss. 21-32. 


\title{
PRZEMIANY NABOŻEŃSTWA DROGI KRZYŻOWEJ W XX WIEKU W ŚWIETLE TEORII AKTÓW MOWY (WYBRANE ASPEKTY)
}

\author{
Streszczenie
}

W artykule opisano zmiany, które zachodzą w nabożeństwie drogi krzyżowej w ciągu ostatniego stulecia. Analiza opiera się na klasyfikacji aktów mowy Searle’a oraz na teorii funkcji wypowiedzi Bühlera-Jakobsona. Siła illokucyjna jest traktowana jako jeden z elementów gatunku mowy, tzw. aspekt pragmatyczny. Materiał badawczy obejmuje 100 tekstów nabożeństwa drogi krzyżowej wydanych przed soborem watykańskim II, w pierwszej połowie XX wieku, i 100 tekstów współczesnych, posoborowych.

Okazuje się, że w badanym okresie zmienia się udział poszczególnych aktów mowy w całości tekstu. Między innymi można zauważyć zmniejszenie roli aktów ekspresywnych, a jednocześnie wzrost roli aktów dyrektywnych. Ponadto o wiele mniejszą wagę we współczesnym nabożeństwie przywiązuje się do aktu deklaratywnego polegającego na uzyskaniu odpustu. Jednakże podstawowy zespół aktów mowy nie zmienia się i w tym sensie można mówić o stałości nabożeństwa drogi krzyżowej.

Słowa kluczowe: akt mowy; funkcja wypowiedzi; droga krzyżowa; pragmalingwistyka; teolingwistyka.

\section{CHANGES OF DEVOTION OF STATIONS OF THE CROSS IN THE 20TH CENTURY ACCORDING TO THE THEORY OF SPEECH ACTS (SELECTED ASPECTS)}

\section{Summary}

The paper describes changes which occurred in service of Stations of the Cross during the last century. The analysis is based on Searle's classification of illocutionary acts and Bühler-Jakobson's theory of speech functions. Illocutionary force is considered as one of the specific features of a speech genre (so called pragmatic aspect). Material of the study includes 100 Polish texts of Stations of the Cross service published during the first half of the 20th century and 100 contemporary texts of the devotional practice (after the II Vatican Council).

The frequency of appearance and significance of different speech acts have changed in the analyzed period. It may be noted, inter alia, reduction of the role of expressive acts, and at the same time increase of the role of directive acts. Clearly less attention is paid to declarational act of gaining of the indulgences. However, basic set of speech acts in the devotion hasn't changed and in this sense we can speak of stability of devotion of Stations of the Cross.

Key words: speech act; speech function; Stations of the Cross; pragmalinguistics; theolinguistics. 